\title{
GAMBARAN EFEK SAMPING METODE KONTRASEPSI JANGKA PANJANG DI KECAMATAN SINGAPARNA KABUPATEN TASIKMALAYA TAHUN 2014
}

Oleh :

Happi Apriasih, S.ST.,M.Kes

\section{A. Abstrak}

Alat kontrasepsi jangka panjang (MKJP) adalah alat kontrasepsi yang digunakan untuk menunda, menjarangkan kehamilan, serta menghentikan kesuburan, yang digunakan dengan jangka panjang, yang meliputi IUD, implant, metode kontrasepsi jangka panjang (MKJP) paling efektif untuk menekan laju pertumbuhan penduduk. Banyak faktor yang mempengaruhi penggunaan MJKP salah satunya adalah keluhan efek samping yang terjadi. Berdasarkan data di Kecamatan Singaparna cakupan penggunaan MJKP masih rendah dibandingkan dengan metode kontrasepsi hormonal.Tujuan penelitian ini adalah mengetahui gambaran efek samping metode kontrasepsi metode jangka panjang di Desa Cikunir Kec Singaparna Kab Tasikmalaya Tahun 2014.

Metode penelitian yang digunakan adalah kuantitatif, jenis penelitian deskriptif. Pengumpuan data yang digunakan adalah data primer dengan instrumen penelitian kuesioner. Sampel terdiri dari 23 orang akspetor KB AKDR dan 1 orang akseptor KB implant. Analisis data yang digunakan adalah univariat.

Hasil penelitian dapat diketahui bahwa sebagian akseptor MJKP mengalami efek samping meskipun tidak semua efek samping terjadi. Untuk kontrasepsi AKDR yang paling banyak adalah perdarahan pada saat haid (30,4\%), keputihan (21,7\%), perdarahan bercak dan diluar haid serta nyeri alat kelamin suami $(4,3 \%)$, nyeri yang berlebih dan mules perut bagian bawah $(2,6 \%)$ dan demam serta keputihan yang berbau (0 \%). Sedangkan Akseptor KB implant dari 1 orang mengalami efek samping berupa tidak haid, rasa nyeri pada lengan dan sakit kepala hebat.

Kesimpulan penelitian ini adalah sebagian akseptor KB jangka panjang mengalami efek samping tetapi tidak sampai mengalami gangguan kesehatan. Saran penelitian ini adalah meningkatkan konseling tentang KB pada pasangan suami istri, menyediakan fasilitas yang memadai, memfasilitasi tenaga kesehatan untuk pelatihan.

\section{Kata Kunci : Efek samping, Metode Kontrasepsi Jangka Panjang}




\section{B. Latar belakang}

Alat kontrasepsi jangka panjang (MKJP) adalah alat kontrasepsi yang digunakan untuk menunda, menjarangkan kehamilan, serta menghentikan kesuburan, yang digunakan dengan jangka panjang, yang meliputi IUD, implant dan kontrasepsi mantap. Indonesia merupakan negara yang dilihat dari jumlah penduduknya ada pada posisi keempat di dunia, dengan laju pertumbuhan yang masih relatif tinggi. Esensi tugas program Keluarga Berencana (KB) dalam hal ini telah jelas yaitu menurunkan fertilitas agar dapat mengurangi beban pembangunan demi terwujudnya kebahagiaan dan kesejahteraan bagi rakyatdan bangsa Indonesia.

Pemakaian kontrasepsi ini sekaligus meningkatkan derajat kesehatan ibu, bayi dan anak serta memberikan konstribusi terhadap panurunan Angka Kematian Ibu (AKI) dan Angka Kematian Bayi (AKB) sehingga membantu terwujudnya keluarga kecil, bahagia dan sejahtera. Kepala Badan Kependudukan dan Keluarga Berencana Nasional (BKKBN) Fasli Jalal mengingatkan bahwa metode kontrasepsi jangka panjang (MKJP) paling efektif untuk menekan laju pertumbuhan penduduk.

Hasil penelitian yang dilakukan oleh Tri Setiowati Di Cimahi Tahun 2008 menunjukkan bahwa terdapat hubungan antara faktor sosio demografi ( $\mathrm{p}$ value 0.001 ), faktor budaya ( $\mathrm{p}$ value $0.0005)$, faktor akses terhadap pelayanan ( $p$ value 0.0005 ) dan faktor sosio psikologi ( $p$ value 0.002) dengan penggunaan $\mathrm{AKD}$, sedangkan gambaran keluhan akibat penggunaan alat kontrasepsi IUD yang telah dilakukan oleh Intan Riyadul Jannah di Puskesmas Sukajadi Kab Bandung didapatkan prosentase akseptor yang mengeluhkan perubahan siklus menstruasi sebanyak 3 akseptor (4.62\%), peningkatan jumlah darah menstruasi 28 akseptor (43.08\%), spooting 18 akseptor (27.69\%), dismenore 13 akseptor (20.00\%), gangguan hubungan seksual akseptor (23.08\%), leukorea 29 akseptor (44.62\%) dan perubahan tekanan darah 49 akseptor (75.38\%).

Berbagai efek samping tersebut dapat menjadi salah satu kendala dalam penggunaan kontrasepsi panjang ditambah jika proses konseling atau KIE (Komunikasi Informasi dan dukasi) dalam KB yang diberikan kurang baik sehingga akseptor tidak paham dengan efek samping yang dapat terjadi dan bagaimana penganggulangannya.

Berdasarkan data profil Puskesmas Singaparna bahwa cakupan peserta KB aktif terjadi penurunan dibanding tahun sebelumnya yaitu sebesar 7400 $(73,03 \%)$ tahun 2012 menjadi 7356 $(71,5 \%)$ tahun 2013, meskipun demikian cakupan peserta KB baru mengalami kenaikan sebesar 5,5\%. Dengan jumlah PUS pada tahun 2012 sebanyak 10132 di tahun 2012 dan mengalami kenaikan menjadi 10289 di tahun 2013. Metode kontrasepsi terpilih peserta KB aktif adalah metode jangka panjang yaitu IUD naik menjadi 14,2\% di tahun 2013 dari 7,85 \% di tahun 2012 dan Implant naik menjadi 2,6 \% di tahun 2013 dari 1,55 $\%$ di tahun 2012, hal tersebut merupakan perubahan positif dalam penggunaan metode jangka panjang tetapi kontrasepsi suntik masih mendapat perhatian yang besar dengan cakupan tertinggi pengunaannya dibandingkan dengan metode kontrasepsi lainnya yaitu $4488(50,3 \%)$ di tahun 2013 . Dari data tersebut dapat diambil kesimpulan bahwa cakupan penggunaan metode kontrasepsi jangka panjang masih relatif sedikit bila dibandingkan dengan metode kontrasepsi lainnya.

Berdasarkan latar belakang di atas maka penulis tertarik untuk melakukan penelitian yang berjudul "Gambaran Efek Samping Metode Kontrasepsi Jangka Panjang di Kecamatan Singaparna Kabupaten Tasikmalaya 
tahun 2014.Penelitian ini bertujuan untuk mengetahui gambaran efek samping metode kontrasepsi metode

\section{Metode}

Penelitian ini merupakan penelitian kuantitatif dengan metode deskriptif, yang bertujuan untuk mengambarkan efek samping penggunaan metode kontrasepsi jangka panjang di $\mathrm{Kec}$ Singaparna Kab Tasikmalaya Tahun 2014.

Populasi penelitian adalah seluruh ibu akseptor KB yang menggunakan metode kontrasepsi jangka panjang yaitu AKDR dan Implant, dengan pengambilan sampel menggunakan teknik total sampling, didapatkan 24 orang akseptor KB terdiri dari 23 akseptor KB AKDR dan 1 akseptor KB Implant.

Instrumen yang digunakan adalah kuesioner berupa angket yang diisi langsung oleh responden. Jumlah soal terdiri dari pertanyaan tertutup dan terbuka mengenai umur, jumlah anak, pendidikan ibu, pekerjaan ibu, penggunaan metode KB , lama penggunaan dan efek samping yang dirasakan selama penggunaan KB tersebut meliputi efek samping penggunaan AKDR. jangka panjang di Kec Singaparna Kab Tasikmalaya Tahun 2014.

\section{Pengolahan Data}

\section{Editing data}

Menyeleksi atau memeriksa kembali data yang telah didapat dari lembar kuesioner apakah lengkap atau tidak.

\section{Coding Data}

Melakukan pengkodean pada data agara tidak terjadi kekeliruan dalam melakukan tabulasi data

\section{Tabulating Data}

Pengelompokkan data ke dalam tabel menurut nilai yang dihasilkan sesuai dengan tujuan penelitian

\section{Entrying data}

Memasukan data ke dalam komputer yang ditampilkan baik berbentuk tabel maupun grafik.

\section{Analisis Data}

Analsis data yang digunakan adalah analisis unvariat. Analisa univariat dilakukan untuk melihat distribusi frekuensi dari variabel dependen. Dibuat tabel istribusi frekuensi dari semua sebaran variabel yang terdapat dalam penelitian ini. Analisa univariat dilakukan dengan menggunakan rumus distribusi frekuensi.

\section{Hasil penelitian}

\section{Umur Ibu}

Tabel Distribusi Frekuensi Umur Ibu yang menggunakan MJKP di desa Cikunir Tahun 2014

\begin{tabular}{|c|l|c|c|}
\hline No & Penggunaan MJKP & Frekuensi & Persentase (\%) \\
\hline 1 & $<20$ tahun & 0 & 0 \\
\hline 2 & $20-35$ tahun & 9 & 37,5 \\
\hline 3 & $>35$ tahun & 15 & 62,5 \\
\hline \multicolumn{2}{|c|}{ Jumlah } & $\mathbf{2 4}$ & $\mathbf{1 0 0}$ \\
\hline
\end{tabular}

Tabel diatas menunjukkan bahwa sebagian besar umur ibu yang menggunakan MJKP adalah ibu yang berumur $>35$ tahun yaitu $62,5 \%$ 
2. Jumlah Anak

Tabel Distribusi Frekuensi Jumlah Anak Ibu yang menggunakan MJKP di desa

Cikunir Tahun 2014

\begin{tabular}{|c|cc|c|c|}
\hline No & \multicolumn{2}{|c|}{ Penggunaan MJKP } & Frekuensi & Persentase (\%) \\
\hline 1 & $\leq 2$ & & 8 & 33,3 \\
\hline 2 & $>2$ & & 16 & 66,7 \\
\hline \multicolumn{2}{|c|}{} & Jumlah & $\mathbf{2 4}$ & $\mathbf{1 0 0}$ \\
\hline
\end{tabular}

Tabel diatas menunjukkan bahwa sebagian besar jumlah anak ibu yang menggunakan MJKP adalah > dari 2 orang anak yaitu $16 \%$.

\section{Pendidikan}

Tabel Distribusi Frekuensi Pendidikan Ibu yang menggunakan MJKP di desa

Cikunir Tahun 2014

\begin{tabular}{|c|l|c|c|}
\hline No & \multicolumn{1}{|c|}{ Penggunaan MJKP } & Frekuensi & Persentase (\%) \\
\hline 1 & Rendah & 11 & 45,8 \\
\hline 2 & Tinggi Jumlah & 13 & 54,2 \\
\hline \multicolumn{2}{|c|}{ Jur| } & $\mathbf{2 4}$ & $\mathbf{1 0 0}$ \\
\hline
\end{tabular}

Tabel diatas menunjukkan bahwa pendidikan ibu yang menggunakan MJKP antara penddikan ibu yang rendah dan tinggi hampir sama meskipun ibu yang berpendidikan tinggi 8, $4 \%$ lebih banyak .

\section{Pekerjaan}

Tabel Distribusi Frekuensi Pekerjaan ibu yang menggunakan MJKP di desa

Cikunir Tahun 2014

\begin{tabular}{|c|l|c|c|}
\hline No & \multicolumn{1}{|c|}{ Penggunaan MJKP } & Frekuensi & Persentase (\%) \\
\hline 1 & Bekerja & 5 & 20.8 \\
\hline 2 & Tidak Bekerja & 19 & 79,2 \\
\hline \multicolumn{2}{|c|}{ Jumlah } & $\mathbf{2 4}$ & $\mathbf{1 0 0}$ \\
\hline
\end{tabular}

Tabel diatas menunjukkan bahwa sebagian besar pekerjaan ibu yang menggunakan MJKP adalah ibu yang tidak bekerja yaitu ibu rumah tangga sebesar 79,2\%.

\section{Penggunaan MJKP}

Tabel Distribusi Frekuensi Penggunaan MJKP di desa Cikunir Tahun 2014

\begin{tabular}{|c|c|c|c|}
\hline No & Penggunaan MJKP & Frekuensi & Persentase (\%) \\
\hline 1 & AKDR & 23 & 95,8 \\
\hline 2 & Implant & 1 & 4,2 \\
\hline \multicolumn{2}{|c|}{ Jumlah } & $\mathbf{2 4}$ & $\mathbf{1 0 0}$ \\
\hline
\end{tabular}

Tabel diatas menunjukkan bahwa hampir seluruh ibu menggunakan MJKP metode KB AKDR yaitu $95,8 \%$ dan hanya 1 orang yang memiih metode KB Implant yaitu 4,2\%.

\section{Lama penggunaan}

Tabel Distribusi Frekuensi Lama Penggunaan MJKP di desa Cikunir Tahun 2014

\begin{tabular}{|c|l|c|c|}
\hline No & Lama Penggunaan MJKP & Frekuensi & Persentase (\%) \\
\hline 1 & $<3$ bulan & 1 & 4,2 \\
\hline 2 & $>3-<1$ tahun & 2 & 8,3 \\
\hline 3 & $>1$ tahun & 21 & 87,5 \\
\hline \multicolumn{2}{|c|}{ Jumlah } & $\mathbf{2 4}$ & $\mathbf{1 0 0}$ \\
\hline
\end{tabular}

Tabel diatas menunjukkan bahwa sebagian lama penggunaan ibu yang menggunakan MJKP adalah > 1 tahun yaitu 87,5\%. 
7. Waktu Penggunaan

Tabel Distribusi Frekuensi Waktu Penggunaan MJKP di desa Cikunir Tahun 2014

\begin{tabular}{|c|l|c|c|}
\hline No & Waktu Penggunaan MJKP & Frekuensi & Persentase (\%) \\
\hline 1 & 3 tahun & 8 & 33,3 \\
\hline 2 & 5 tahun & 5 & 20,8 \\
\hline 3 & 10 tahun & 11 & 45,8 \\
\hline \multicolumn{2}{|c|}{ Jumlah } & $\mathbf{2 4}$ & $\mathbf{1 0 0}$ \\
\hline
\end{tabular}

Tabel diatas menunjukkan bahwa sebagian bssar waktu penggunaan MJKP yang dipiilih adalah > 10 tahun yaitu 45,8\%

\section{Tempat dipasang}

Tabel Distribusi Frekuensi Tempat dipasang MJKP di desa Cikunir Tahun 2014

\begin{tabular}{|c|l|c|c|}
\hline No & Lama Penggunaan MJKP & Frekuensi & Persentase (\%) \\
\hline 1 & Puskesma & 1 & 4,2 \\
\hline 2 & Rumah Sakit & 15 & 62,5 \\
\hline 3 & Bidan Praktik Swasat & 8 & 33,3 \\
\hline \multicolumn{2}{r|}{ Jumlah } & $\mathbf{2 4}$ & $\mathbf{1 0 0}$ \\
\hline
\end{tabular}

Tabel diatas menunjukkan bahwa sebagian besar tempat pemasangan MJKP adalah di Rumah Sakit yaitu 62,5\%.

\section{Dukungan}

Tabel Distribusi Frekuensi Dukungan MJKP di desa Cikunir Tahun 2014

\begin{tabular}{|c|l|c|c|}
\hline No & Lama Penggunaan MJKP & Frekuensi & Persentase (\%) \\
\hline 1 & Suami & 22 & 91,7 \\
\hline 2 & Keluarga & 2 & 8,3 \\
\hline \multicolumn{2}{|c|}{ Jumlah } & $\mathbf{2 4}$ & $\mathbf{1 0 0}$ \\
\hline
\end{tabular}

Tabel diatas menunjukkan bahwa sebagian besar dukungan ibu yang menggunakan MJKP adalah dari suami yaitu 91,7 \% .

\section{Efek Samping}

1) Tabel Distribusi Frekuensi Efek Samping AKDR di desa Cikunir Tahun 2014

\begin{tabular}{|c|l|c|c|}
\hline No & \multicolumn{1}{|c|}{ Efek Samping AKDR } & Frekuensi & Persentase (\%) \\
\hline 1 & Perdarahan pada saat haid & 7 & 30,4 \\
\hline 2 & Perdarahan bercak & 1 & 4,3 \\
\hline 3 & Perdarahan diluar haid & 1 & 4,3 \\
\hline 4 & $\begin{array}{l}\text { Nyeri yang berlebih pada saat } \\
\text { haid }\end{array}$ & 6 & 26 \\
\hline 5 & Keputihan & 5 & 21,7 \\
\hline 6 & $\begin{array}{l}\text { Nyeri mules kram perut bagian } \\
\text { bawah }\end{array}$ & 6 & 4,3 \\
\hline 7 & $\begin{array}{l}\text { Nyeri alat kelamin suami pada } \\
\text { saat berhubungan }\end{array}$ & 1 & 0 \\
\hline 8 & Demam & 0 & 0 \\
\hline 9 & Keputihan yang berbau & 0 & . \\
\hline
\end{tabular}

Tabel diatas menunjukkan bahwa efek samping penggunaan KB AKDR rata-rata yang banyak dirasakan ibu adalah perdarahan pada saat haid, nyeri yang berlebih pada saat haid dan nyeri mules kram perut bagian bawah meskipun perdarahan pada saat haid adalah efek samping yang paling banyak dirasakan ibu yaitu sebesar 30,4 $\%$. 
2) Tabel Distribusi Frekuensi Efek Samping Implant di desa Cikunir Tahun 2014

\begin{tabular}{|c|l|c|c|}
\hline No & \multicolumn{1}{|c|}{ Efek Samping Implant } & Frekuensi & $\begin{array}{c}\text { Persentase } \\
(\%)\end{array}$ \\
\hline 1 & Tidak Haid & 1 & 100 \\
\hline 2 & Perdarahan yang banyak dari kemaluan & 0 & \\
\hline 3 & Rasa nyeri pada lengan & 1 & 100 \\
\hline 4 & Luka bekas insisi mengeluarkan darah atau nanah & 0 & \\
\hline 5 & Keluarnya batang implant dari lengan & 0 & \\
\hline 6 & Sakit kepala hebat/penglihatan kabur & 1 & 100 \\
\hline 7 & Nyeri dada hebat & 0 & \\
\hline
\end{tabular}

Tabel diatas menunjukkan bahwa efek samping metode KB implant yang sering ibu rasakan adalah tidak haid, rasa nyeri pada lengan dan sakit kepala hebat atau penglihatan kabur.

\section{E. Pembahasan}

\section{Efek samping metode KB AKDR}

Berdasarkan hasil penelitian mengenai gambaran efek samping metode kontrasepsi jangka panjang yaitu metode KB AKDR didapatkan bahwa efek samping rata-rata yang banyak dirasakan ibu adalah perdarahan pada saat haid, nyeri yang berlebih pada saat haid dan nyeri mules kram perut bagian bawah meskipun perdarahan pada saat haid adalah efek samping yang paling banyak dirasakan ibu yaitu sebesar 30,4 $\%$. Data tersebut menunjukan bahwa hanya 3 efek samping dari 9 efek samping yang biasa dirasakan ibu pengguna metode $\mathrm{KB}$ AKDR, menurut asumsi peneliti kondisi efek samping yang terjadi merupakan hal yang masih normal sebagai akibat dari efek alat atau benda asing yang masuk ke dalam alat reproduksi perempuan yaitu rahim yang akan merangsang terjadinya kontrasi sehingga akan merasakan adanya kram dan nyeri pada saat haid, tetapi efek samping tersebut akan terjadi sesuai dengan kondisi masing-masing individu pengguna $\mathrm{KB} A K D R$, mengingat adaptasi tubuh terhadap kontrasepsi tidak sama setiap individu.

Berdasarkan data hasil penelitian didapatkan bahwa lama penggunaan KB AKDR sebagian besar lebih dari 1 tahun, dapat diartikan sebetulnya kondisi yang terjadi pada akseptor KB tesebut sebetulnya sudah bukan merupakan efek samping melainkan gangguan, meskipun demikian berdasarkan hasil penelitian juga tidak ada ibu yang drop out atau ganti acara dengan menggunakan metode kontrasepsi lain ketika terjadi gangguan tersebut, karena kemungkinan gangguan tersebut tidak menjadi masalah yang besar bagi akseptor tersebut.

\section{Efek samping metode KB Implant}

Berdasarkan hasil penelitian didapatkan bahwa efek samping metode KB implant yang sering ibu rasakan adalah tidak haid, rasa nyeri pada lengan dan sakit kepala hebat atau penglihatan kabur meskipun tergambar hanya dari satu orang responden tetapi tetap memberikan informasi mengenai gambaran efek samping tersebut, berbeda dengan metode KB AKDR metode KB Implant merupakan kontrasepsi yang mengandung hormon progesteron seperti yang kita ketahui bahwa kontrasepsi yang mengandung hormon progesteron mempunyai efek sistemik terhadap tubuh pengguna yaitu sering dikaitkan dengan peningkatan tekanan darah sehingga salah satunya dapat mengakibatkan sakit kepala hebat bahkan sampai penglihatan kabur sehingga tidak dianjurkan bagi ibu yang mempunyai riwayat tekanan darah tinggi, ibu menjadi tidak haid karena mekanisme kerja kontrasepsi implant salah satunya adalah dapat menekan ovulasi sehingga perdarahan tidak 
terjadi, selain itu rasa nyeri pada lengan karena metode kontrasepsi implant prinsip pemasangannya didahului dengan proses insisi untuk memasukkan kapsul implant, tetapi jika perawatan yang dilakukan benar kondisi tersebut akan hilang dalam beberapa hari pasca pemasangan, tetapi disisi lain metode KB implant mmpunyai keuntungan diantaranya perlindungan jangka panjang pengembalian tingkat kesuburan yang cepat, tidak memerlukan pemeriksaan dalam, tidak mengganggu kegiatan sanggama, tidak mengganggu ASI, klien hanya perlu ke klinik bila ada keluhan, dan dapat dicabut setiap saat sesuai dengan kebutuhan.

Disamping hal tersebut di atas hasil penelitian menunjukkan bahwa dilihat dari umur ibu yang menggunakan metode KB Jangka Panjang adalah umur ibu yang lebih dari 35 tahun yaitu sebanyak $62,5 \%$. Menurut Elisabeth $\mathrm{BH}$ yang dikutip Nursalam (2003), usia adalah umur individu terhitung mulai saat dilahirkan sampai berulang tahun, dimana dengan bertambahnya umur seseorang diiringi dengan berbagai pengalaman hidup yang berdampak pada bagaimana pemilihan seseorang terhadap penggunaan metode kontasepsi, hal ini sejalan dengan Huclok (1998) yang menyebutkan bahwa semakin cukup umur, tingkat kematangan dan kekuatan seseorang akan lebih matang dalam berfikir dan bekerja. Dari segi kepercayaan masyarakat seseorang yang lebih dewasa dipercaya dari pada orang yang belum tinggi kedewasaannya (A. Wawan, dkk., 2010). Jadi akseptor yang sudah matang baik dari segi fisik dan psikologisnya akan lebih memilih metode kontrasepi jangka panjang, tetapi berdasarkan teori bahwa penggunaan metode kontrasepsi jangka panjang tidak dipengaruhi oleh matang tidaknya umur seseorang melainkan metode jangka panjang sebetulnya bisa dipakai oleh ibu yang belum mempunyai anak sekalipun, karena salah satu keuntungan metode $\mathrm{KB}$ tersebut yaitu dari segi keseburan akan cepat kembali ke semula pasca pemasangan.

Dari tingkat pendidikan sebagian besar ibu pengguna metode jangka panjang ini adalah berpendidikan tinggi yaitu 54,2 \%. Pendidikan merupakan salah satu faktor internal yang mempengaruhi seseorang dalam pola hidup terutama motivasi untuk sikap berperan serta dalam pembangunan kesehatan, makin tinggi tingkat pendidikan seseorang makin mudah menafsirkan informasi sehingga meciptakan suatu hal yang baik sebaliknya pendidikan yang kurang akan menghambat penfsiran informasi seseorang terhadap objek baru diperkenalkan (A Wawan, DKK,, 2010). Dalam hal ini pendidikan mempunyai peran yang besar dalam mempengaruhi seseorang untuk memilih metode kontrasepsi, sehingga mereka berupaya untuk memilih yang terbaik terlebih jika mengetahui bahwa penggunaan KB yang paling efektif adalah metode jangka panjang dilihat dari tingkat kegagalannya yang rendah dan efek samping yang relatif jarang dirasakan oleh pengguna.

Berdasarkan hasil penelitian dilihat dari jumlah anak didapatkan bahwa sebagian besar jumlah anak ibu yang menggunakan metode kontrasepsi jangka panjang adalah lebih dari 2 anak yaitu 66,7 \%. Menurut wawan A, dkk., (2010) yang menyebutkan bahwa pada ibu dengan jumlah anak lebih dari 2 atau paritas tinggi akan lebih menimbulkan risiko atau bahaya pada ibu dan bayi, dengan demikian ibu akan lebih memilih metode kontasepsi yang dapat membatasi jumlah anak dalam jangka panjang sehingga resiko tersebut tidak akan terjadi. Tetapi berbanding terbalik dengan teori yang menyebutkan bahwa penggunaan metode jangka panjang tidak harus selalu ibu dengan paritas tinggi, karena yang belum punya anak 
sekalipun dapat menggunakan metode jangka panjang mengingat efek kesuburannya yang relatif cepat pasca proses pencabutan.

Dari pembahasan tersebut dapat diambil kesimpulan bahwa efek samping akseptor metode KB jangka panjang yaitu AKDR dan Implant hanya terjadi pada kurang dari $50 \%$ pengguna kondisi tersebut pun tidak menimbulkan masalah yang besar bagi akseptor karena tidak ada akseptor yang DO (drop Out) berhenti atau ganti cara dengan metode kontrasepsi yang lain, didukung oleh tingkat pemahaman baik tentang kontrasepsi jangka panjang tersebut, hanya saja permasalahannya adalah cakupan metode KB panjang yang masih rendah sedangkan pemerintah sendiri menargetkan cakupan akseptor MJKP dalam RJPMN 2010 yaitu lebih dari $25,9 \%$ mengingat efektifitas dari metode KB tersebut, oleh karena itu tidak lepas dari peran tenaga kesehatan yang harus mengoptimalkan upaya konseling kepada seluruh pasangan usia subur terutama bagi yang tingkat pendidikan yang rendah karena terkait dengan pemahaman sehingga dapat termotivasi untuk menggunakan metode jangka panjang.

\section{F. Simpulan dan saran}

Berdasarkan hasil penelitian mengenai gambaran efek samping penggunaan metode jangka panjang di Desa Cikunir Kecamatan Singaparna Kabupaten Tasikmalaya Tahun 2014 adalah kurang dari 50 persen ibu akseptor KB jangka panjang mengalami efek samping dan kondisi tersebut tidak menjadi sebuah masalah sehingga tetap aktif menggunakan metode KB tersebut.

Rekomendasi penelitian adalah Meningkatkan konseling bagi pasangan usia subur (PUS) sehingga dapat meningkatkan pemahaman PUS mengenai metode kontrasepsi jangka panjang dan termotivasi untuk menggunakan $\mathrm{KB}$ tersebut sehingga cakupan KB tersebut akan meningkat dan target pemerintah akan tercapai dan meningkatkan keterampilan dengan mengikuti pelatihan.

\section{G. Referensi}

Saifuddin, Abdul bari, dkk. 2003. Buku Panduan Praktis Pelayanan Kontrasepsi. Jakarta : YBP Sarwono Prawirohardjo.

Saifuddin, Abdul bari, dkk. 2002. Buku Acuan Nasional Pelayanan Kesehatan Maternal dan Neonatal, Jakarta : YBP Sarwono Prawirohardjo.

Hartanto Hanafi. 2003.Keluarga Berencana dan Kontrasepsi. Jakarta : Pustaka Sinarharapan.

Manuaba, Ida Bagus Gde.1998.Ilmu Kebidanan, Penyakit Kandungan, \& KB untuk Pendidikan Bidan. Jakarta : EGC.

Mardiya. 2002. Petunjuk Praktis Cara Memilih Kontrasepsi. Yogyakarta : Liberty Yogyakarta.

Wiknjosastro Hanifa, dkk. 2002 .Ilmu kebidanan. Jakarta : YBP - SP.

Baziad Ali, 2002. Kontrasepsi Hormonal. Jakarta. YBP Sarwono Prawirohardjo.

Meilani Niken, dkk. 2010. Pelayanan Keluarga

Berencana.Yogyakarta. Fitramaya

Rencana Kerja Pemerintah (RKP) Tahun 2014 